\title{
Hoverfly (Diptera: Syrphidae) richness and abundance vary with forest stand heterogeneity: Preliminary evidence from a montane beech fir forest
}

\author{
Laurent LARRIEU ${ }^{1,2}$, Alain CABANETTES ${ }^{1}$ and JeAn-Pierre SARTHOU ${ }^{3,4}$ \\ ${ }^{1}$ INRA, UMR1201 DYNAFOR, Chemin de Borde Rouge, Auzeville Tolosane, CS 52627, F-31326 Castanet Tolosan Cedex, France; \\ e-mails: laurent.larrieu@toulouse.inra.fr; alain.cabanettes@toulouse.inra.fr \\ ${ }^{2} \mathrm{CNPF} / \mathrm{IDF}$, Antenne de Toulouse, 7 chemin de la Lacade, F-31320 Auzeville Tolosane, France \\ ${ }^{3}$ INRA, UMR 1248 AGIR, Chemin de Borde Rouge, Auzeville Tolosane, CS 52627, F-31326 Castanet Tolosan Cedex, France; \\ e-mail: jean-pierre.sarthou@toulouse.inra.fr \\ ${ }^{4}$ University of Toulouse, INP-ENSAT, Avenue de l'Agrobiopôle, F-31326 Castanet Tolosan, France
}

Key words. Diptera, Syrphidae, Abies alba, deadwood, Fagus silvatica, functional diversity, tree-microhabitats, stand heterogeneity

\begin{abstract}
Hoverflies (Diptera: Syrphidae) provide crucial ecological services and are increasingly used as bioindicators in environmental assessment studies. Information is available for a wide range of life history traits at the species level for most Syrphidae but little is recorded about the environmental requirements of forest hoverflies at the stand scale. The aim of this study was to explore whether the structural heterogeneity of a stand influences species richness or abundance of hoverflies in a montane beech-fir forest. We used the catches of Malaise traps set in 2004 and 2007 in three stands in the French Pyrenees, selected to represent a wide range of structural heterogeneity in terms of their vertical structure, tree diversity, deadwood and tree-microhabitats. We assessed hoverfly assemblages by recording species richness, abundance and functional diversity. Malaise traps caught 2,374 hoverflies belonging to 104 species. The catches of hoverflies fluctuated both in species richness and abundance between 2004 and 2007. Strictly forest species were only caught in the most heterogeneous stand. Species strictly associated with fir were not recorded in the least heterogeneous stand although fir was present. Although most of the functional groups were recorded in the three stands, species richness, abundance and functional diversity decreased dramatically from the most heterogeneous to the least heterogeneous stand. However, the species assemblages in the less heterogeneous stands were not perfect subsets of that in the most heterogeneous stand, as some additional species not found in the most heterogeneous stand were also present.
\end{abstract}

\section{INTRODUCTION}

There are 534 species of hoverflies (Diptera: Syrphidae) recorded in France (Speight et al., 2013). Larvae have a wide range of feeding habits and are involved in recycling of deadwood (Speight, 1989) and regulating the abundance of pests (i.e. Smith et al., 2008; Rotheray \& Gilbert, 2011; Nelson et al., 2012). Adults of all the species are floricolous and pollinate plants (Jarlan et al., 1997; Frank \& Volkmar, 2006; Gibson et al., 2006), probably even trees and shrubs (Groot \& Bevk, 2012). Given the general agreement on the insurance hypothesis, i.e. a high level of biodiversity could insure ecosystems against decline in their functioning linked to environmental fluctuations (Yachi \& Loreau, 1999; Tscharntke et al., 2012), as the preservation of the highest possible species richness of such important biological groups is of the utmost importance in the current context of global change. Functional diversity (FD) measures functional trait diversity within assemblages and hence is a component of biodiversity (Petchey \& Gaston, 2006) and determines ecosystem processes (e.g. Loreau et al., 2001). FD makes it possible to analyze variations in an assemblage in terms of alterations in ecosystem properties (Loreau et al., 2001).

The "Syrph the Net" database (Speight et al., 2013) lists a wide range of the life history traits of species. However, despite the popularity of hoverflies among naturalists and their use as indicator species at the landscape scale (Sommaggio \& Burgio, 2003) and for identifing forests of conservation value (Speight, 1989; Good \& Speight, 1996), literature on the environmental requirements of forest hoverflies at the stand scale is very rare and our understanding of the structure of local assemblages weak (Keil \& Konvicka, 2005). Nevertheless, notable contributions on this topic are those of Humphrey et al. (1999), who highlight a correlation between vertical stand structure and hoverfly diversity, Fayt et al. (2006), who found that saproxylic assemblages may be constrained by the absence of a rich herbaceous plant layer that provides the floral resources they require for reproduction and Gittings et al. (2006) and then Ricarte et al. (2011), who highlight the positive role of the supply of floral resources in open areas in woodlands in determining hoverfly diversity at both stand and landscape scales.

Beech/fir (Fagus silvatica L. - Abies alba Mill.) forest is a dominant in most European mountain ranges and covers $380,000 \mathrm{~km}^{2}$ (4\% of the total forested area in Europe) (MCPFE, 2007; EUFORGEN, 2012). These forests are known for their key role in the conservation of forest biodiversity. Müller et al. (2012) show that beech-dominated forests are an umbrella habitat for central European saproxylic beetles since $70 \%$ of these species can be found in such forests. However, these forests are also of great eco- 


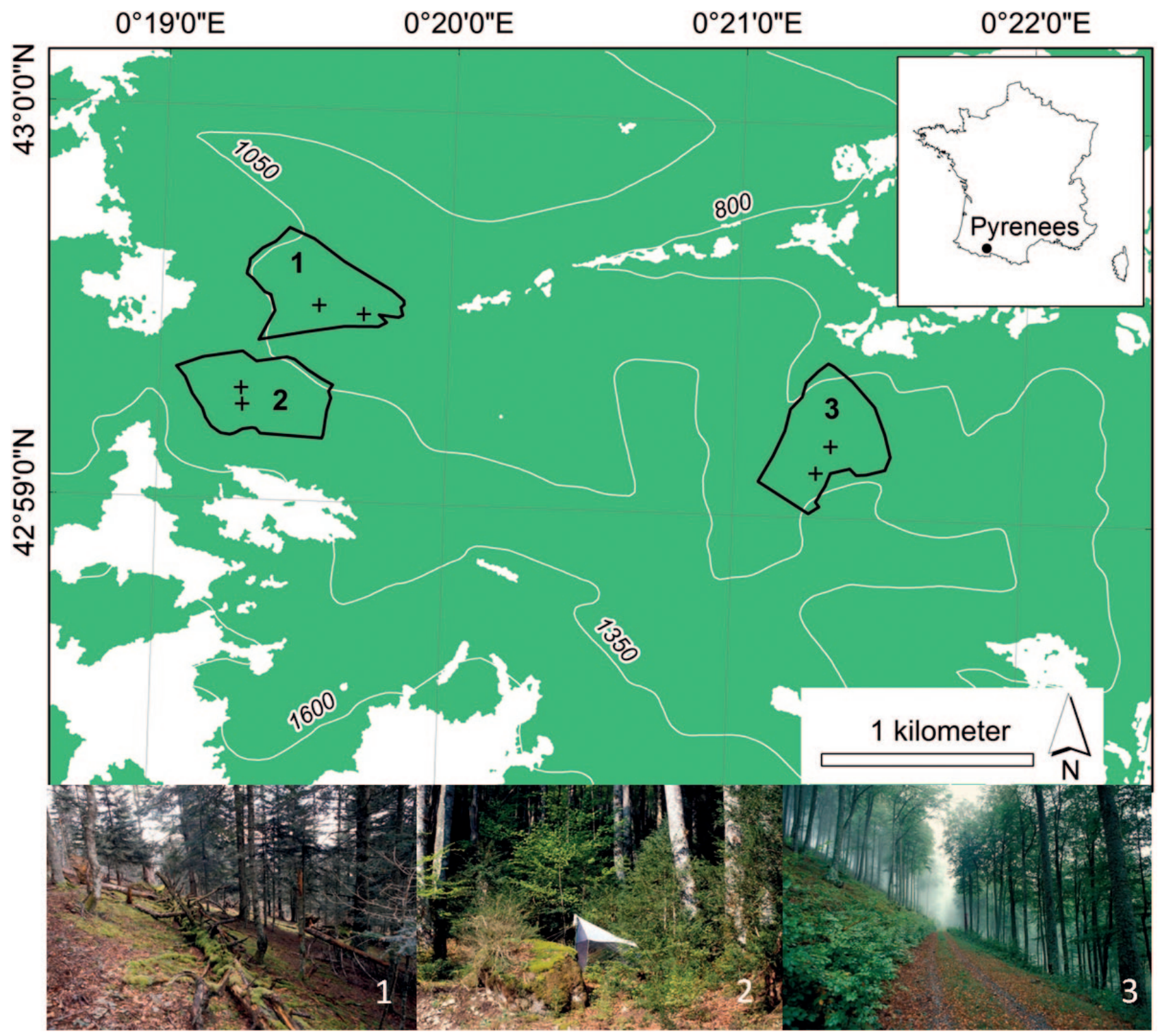

Fig. 1. Map showing the geographical location below which are pictures of the stands studied. 1 - UnHarv100;2 - UnHarv50;3 Harv.

nomic value and most have been managed for a long time, which has had a major effect on their structural heterogeneity. Old management practices reduced their dendrological diversity by favouring beech at the expense of fir (Metailié, 2001). Furthermore, current management (i) also seriously upsets the structure and dynamics of the stock of deadwood by reducing the total amount and number of decay stages (Larrieu et al., 2012), (ii) reduces the number of microhabitat bearing trees (Winter \& Möller, 2008; Larrieu et al., 2014) and (iii) disturbs the tree-microhabitat assemblages by favouring certain types of microhabitat while others become rare or disappear (Larrieu et al., 2012).

This preliminary study explores whether the species richness or abundance of hoverflies is associated with the structural heterogeneity at the stand scale in a montane beech-fir forest. We compare hoverfly assemblages in three stands with different management histories, which have resulted in different structural heterogeneities, in the same forest and so control for both variations in other environ- mental factors and differences in the biogeographic pool of species.

\section{MATERIAL AND METHODS}

\section{Stands studied and measurement of structural features}

The three stands studied are located in the same area in the foothills of the central Pyrenees (France; WGS 84, Lat/Long: $42^{\circ} 59^{\prime} \mathrm{N} / 0^{\circ} 20^{\prime} \mathrm{E}$ ) (Fig. 1). They are natural habitats of montane beech-fir forest (Fagion sylvaticae, Bardat et al., 2004). Since limestone is the dominant substrate, the soils are rich. All the stands studied are in an ancient forest referred to in old maps drawn in the second half of the $19^{\text {th }}$ century, which, in France, was the period when the forested area was lowest (Dupouey et al., 2007).

The three stands differed in terms of their structure, mainly determined by management (Table 1). "UnHarv100" was the most mature as no logging has occurred there since 1900. "UnHarv50" was mostly dominated by beech, in a zone logged using a gravity cable technique in 1950 and not managed since. "Harv" was mostly dominated by beech and has been regularly logged over the last 25 years. Information was recorded for 29 plots between 
TABLE 1. Sample design and main characteristics of the stands studied. dbh - diameter at breast height; SE - standard error.

\begin{tabular}{|c|c|c|c|c|c|c|c|c|c|c|c|}
\hline \multirow[t]{2}{*}{ Stand } & \multirow[t]{2}{*}{$\begin{array}{l}\text { Management } \\
\text { history }\end{array}$} & \multirow[t]{2}{*}{$\begin{array}{l}\text { Study } \\
\text { area } \\
\text { (ha) }\end{array}$} & \multirow[t]{2}{*}{$\begin{array}{l}\text { No. } \\
\text { of } \\
\text { plots }\end{array}$} & \multirow[t]{2}{*}{$\begin{array}{l}\text { No. } \\
\text { of } \\
\text { live } \\
\text { trees } \\
\text { mea- } \\
\text { sured }\end{array}$} & \multirow[t]{2}{*}{$\begin{array}{c}\text { Dendrometric } \\
\text { structure } \\
\text { (see also } \\
\text { Fig. S1) }\end{array}$} & \multirow[t]{2}{*}{$\begin{array}{l}\text { Dendrological } \\
\text { composition }\end{array}$} & \multirow[t]{2}{*}{$\begin{array}{c}\text { Basal area } \\
\mathrm{G}\left(\mathrm{m}^{2} / \mathrm{ha}\right) \\
\text { standing } \\
\text { deadwood } \\
+ \text { living trees } \\
\text { Mean }[\mathrm{CI}]\end{array}$} & \multirow[t]{2}{*}{$\begin{array}{l}\text { No. of } \\
\text { items } \\
\text { of dead } \\
\text { wood } \\
\text { mea- } \\
\text { sured }\end{array}$} & $\begin{array}{c}\text { Diameter at } \\
\text { breast height } \\
(\mathrm{cm}) \\
\text { mean } \\
(\text { min-max }) \\
\end{array}$ & \multirow[t]{2}{*}{$\begin{array}{c}\text { No. of } \\
\text { very large } \\
\text { trees } \\
(\mathrm{dbh}> \\
70 \mathrm{~cm}) \\
\text { per ha }\end{array}$} & \multirow[t]{2}{*}{$\begin{array}{l}\text { Total volume } \\
\text { of deadwood } \\
\left(\mathrm{m}^{3} / \mathrm{ha}\right)[\mathrm{SE}] \\
\text { and decay } \\
\text { stages }\end{array}$} \\
\hline & & & & & & & & & $\overline{\text { beech fir }}$ & & \\
\hline UnHarv100 & $\begin{array}{l}\text { Not logged } \\
\text { since } 1900\end{array}$ & 23 & 10 & 371 & Irregular & $\begin{array}{l}\text { Dominated by fir } \\
\text { and beech }+ \text { Acer } \\
\text { campestre, } \text { A. plat- } \\
\text { anoides, Prunus } \\
\text { avium, Taxus } \\
\text { baccata } \text { and Tilia } \\
\text { platyphyllos }\end{array}$ & $40[33-48]$ & 84 & $\begin{array}{cc}62.9 & 44.4 \\
(15.9- & (8.0- \\
127.3) & 124.1)\end{array}$ & 18 & $\begin{array}{c}32[8.38] \\
\text { Main decay } \\
\text { stage }=4\end{array}$ \\
\hline UnHarv50 & $\begin{array}{l}\text { Intensively logged in } \\
1950, \text { not logged since }\end{array}$ & 20 & 9 & 286 & $\begin{array}{l}\text { Almost } \\
\text { regular }\end{array}$ & $\begin{array}{l}\text { Dominated by } \\
\text { beech; scarce firs }\end{array}$ & $36.5[32-42]$ & 124 & $\begin{array}{cc}42.8 & 43.3 \\
(17.5- & (20.7- \\
87.5) & 82.8)\end{array}$ & 2 & $\begin{array}{c}55[12.73] \\
\text { Main decay } \\
\text { stage }=2\end{array}$ \\
\hline Harv & $\begin{array}{l}\text { Logged twice by selec- } \\
\text { tive logging in the last } \\
25 \text { years (total logged } \\
\text { volume }=50 \mathrm{~m}^{3} \mathrm{ha}^{-1} \text { ) }\end{array}$ & - & 10 & 280 & Regular & $\begin{array}{l}\text { Almost pure } \\
\text { beech stand }\end{array}$ & 35 [31-39] & 73 & $\begin{array}{lc}45.6 & 11.1 \\
(4.8- & (11.1- \\
73.2) & 11.1)\end{array}$ & 1 & $\begin{array}{c}9[2.34] \\
\text { Decay stages } \\
1,2 \text { and } 5 \\
\text { missing }\end{array}$ \\
\hline
\end{tabular}

2003 and 2005 (Table 1). All the plots were sampled using a Bitterlich relascope (Bitterlich, 1984). In order to more accurately record the variability $9-10$ plots were sampled in each stand. Each plot was on average 0.3 ha in area.

The structural heterogeneity of the stands was described in terms of the vertical structure of the vegetation, tree diversity, deadwood and tree-microhabitats (see details of protocols in Table 2). We used the stratiscope method (Blondel \& Cuvillier, 1977) to describe the spatial heterogeneity in the distribution of foliage, both vertically and horizontally. Vegetation layers were surveyed at seven points separated from each other by $5 \mathrm{~m}$ along horizontal transects centered on each plot. All contacts of the foliage with a virtual vertical cylinder $50 \mathrm{~cm}$ in diameter were noted in 4 strata $(<1 \mathrm{~m}, 1-3 \mathrm{~m}, 3-10 \mathrm{~m}, 10-20 \mathrm{~m}$ and $\geq 20 \mathrm{~m})$. All the living trees measured using a relascope were identified to species and their diameters measured at breast height (dbh) on top of the bark. The tree trunks were carefully examined from the ground to the top of the canopy and presence/absence of eight microhabitats on the visible part of the trunk both beneath and within the tree crown were recorded (Table 2). All dead wood greater in diameter than $20 \mathrm{~cm}$ was identified and its length and girth measured, and classified on a decay scale of 1-5 (Table S1).

\section{Heterogeneity of the stands}

The gradient in heterogeneity from UnHarv100 (the most heterogeneous stand) to Harv (the least heterogeneous) revealed: (i) a change from an irregular to a regular dendrometric structure (Fig. S1), (ii) a decrease in tree diversity and increase in the rarity of fir (Fig. S1), (iii) a decrease in the number of very large trees ( $\mathrm{dbh}>70 \mathrm{~cm})$ (Fig. S1), (iv) a decrease in the total volume of deadwood and absence of several decay stages (Table S3), (vi) marked differences in numbers of certain tree-microhabitats (Table S3) and finally (vii) a decrease in the complexity of the structure of the foliage associated with the loss of grassy open areas (Fig. 2). UnHarv100 had a vegetation structure (Fig. 2, left part) in which percentage cover of each of the four upper strata was more than $70 \%$, with an alternation of plants and litter in the lower stratum. No vertical transect showed any contact (right part of Fig. 2), since herbaceous species filled clearings. Shrubs occupied part of stratum 2, containing flowers, at least in clear-

TABLE 2. Components of structural heterogeneity, ecological variables and field procedures used to describe the structural heterogeneity of the stands.

\begin{tabular}{lll}
\hline $\begin{array}{l}\text { Components of structural } \\
\text { heterogeneity }\end{array}$ & Ecological variables & Field procedure used to record the variable \\
\hline $\begin{array}{l}\text { Dendrological } \\
\text { diversity }\end{array}$ & Tree species. & Identification of each tree in the plot at species level. \\
\hline $\begin{array}{l}\text { Dendrometric } \\
\text { heterogeneity }\end{array}$ & $\begin{array}{l}\text { Distributions of the diameters } \\
\text { recorded at breast height for } \\
\text { each species of tree. }\end{array}$ & Measurement of the diameter of each tree in the plot. \\
\hline Vegetation structure & $\begin{array}{l}\text { Number of vertical } \\
\text { and horizontal contacts } \\
\text { with vegetation strata. }\end{array}$ & $\begin{array}{l}\text { All foliage contacts measured with a virtual vertical cylinder (diameter } 50 \mathrm{~cm} \text { ) in } 5 \text { strata } \\
(<1 \mathrm{~m}, 1-3 \mathrm{~m}, 3-10 \mathrm{~m}, 10-20 \mathrm{~m} \text { and } \geq 20 \mathrm{~m} \text { ). Variable recorded at seven points separated } \\
\text { from each other by } 5 \mathrm{~m} \text { along horizontal transects centered on the plot; 10 plots per stand. } \\
\text { Type of contact (herbaceous vs. ligneous plant). }\end{array}$ \\
\hline $\begin{array}{l}\text { Total volume per hectare. } \\
\text { Pattern of distribution of the } \\
\text { volume per tree-species and } \\
\text { decay stage. }\end{array}$ & $\begin{array}{l}\text { For each deadwood item, we (1) identified the tree species, (2) measured the diameter in the } \\
\text { middle of logs and snags of under 4 m, at the cut for high stumps, and at breast height for } \\
\text { snags of over 4 m and (3) recorded the stage of decay using a reference scale with 5 levels } \\
\text { (Table S1). }\end{array}$ \\
\hline $\begin{array}{l}\text { Density per hectare. } \\
\text { Number of microhabitat } \\
\text { types. }\end{array}$ & $\begin{array}{l}\text { Set of } 8 \text { microhabitat types recorded on the visible part of the trunk both beneath and inside } \\
\text { the tree crown: (1) four cavity types on living trees and snags; (2) cracks in the tree trunk, } \\
\text { on living trees and snags; (3) dendrothelms on living trees; (4) sporophores of polypores, on } \\
\text { living trees, snags and logs. Each tree or wood item recorded was classified with respect to } \\
\text { the absence or presence of sporophores, without estimating their numbers; (5) missing bark } \\
\text { only on living trees. (See details, such as size thresholds, in Larrieu et al., 2012.) }\end{array}$ \\
\hline
\end{tabular}



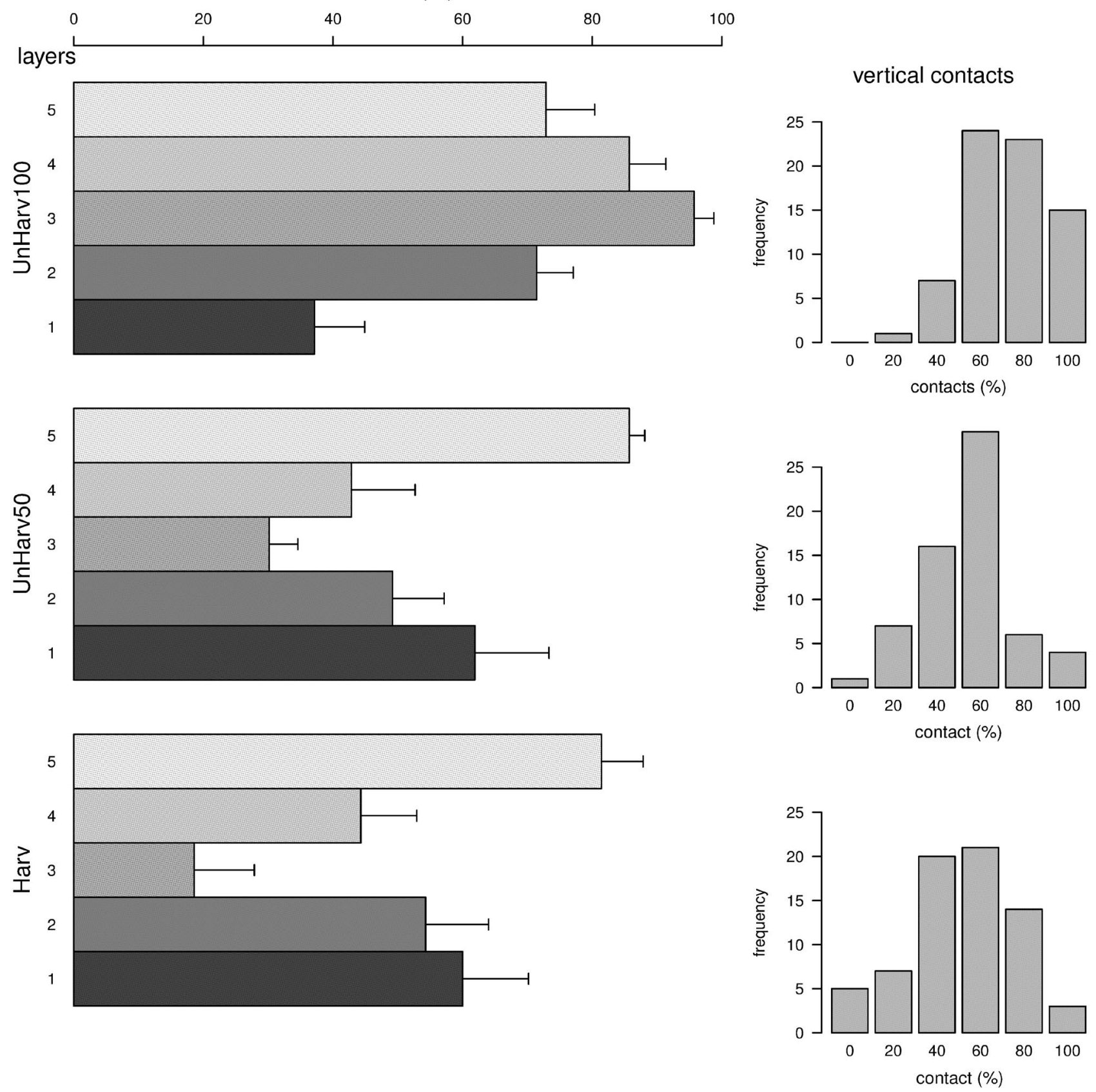

Fig. 2. Foliage distribution in the three beech-fir stands studied (Harv, UnHarv50 and UnHarv100). The mean and standard error of the $\%$ of contacts per layer, (layer 1: contacts between ground and $1 \mathrm{~m} ; 2: 1-3 \mathrm{~m} ; 3: 3-10 \mathrm{~m} ; 4: 10-20 \mathrm{~m} ; 5$ : over $20 \mathrm{~m}$; is indicated on the left for each stand. For details of the procedure, see Table 2). This illustrates the average vertical footprint of vegetation layers at the plot scale (vertical heterogeneity of the vegetation). On the right, the figures shows mean frequencies for 6 levels of $\%$ of all the vegetation contacts (all layers pooled). This illustrates the horizontal distribution of the different levels of vertical vegetation footprints (horizontal heterogeneity of vegetation).

ings. UnHarv50 and Harv had a less heterogeneous structure than UnHarv100, with less cover in the intermediate stratum (stratum 3). In these stands, the lower stratum mainly consisted of beech seedlings, shrubs were rare and the distribution of vertical contacts with vegetation indicates there were many vertical transects with $<20 \%$ contacts.

Only the most mature beech-fir stand, UnHarv100, which has not been logged since 1900, had a structural heterogeneity close to that recorded in sub-natural stands, i.e. a complex vegetation structure with grassy clearings, high dendrological diversity, many very large trees and typical quantities of deadwood and numbers of microhabitats (Greenberg et al., 1997; Nilsson et al., 2002; Christensen et al., 2005; Larrieu et al., 2012, 2014). The vegetation structure at UnHarv50, which has not been logged since 1950, was less complex with a lower dendrological diversity and only the occasional coniferous tree. Harv, which has been regularly logged over the last 25 years, had the simplest structure, with marked dominance of beech, a very small quantity of deadwood and absence of several stages of deadwood decay. 


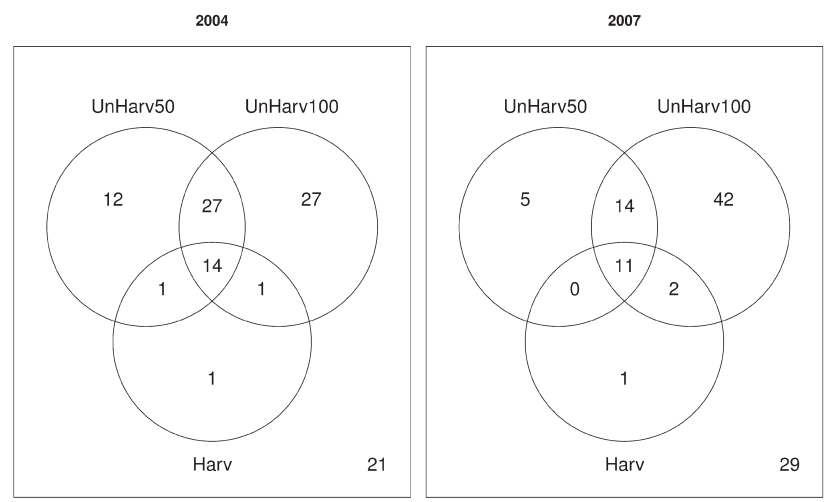

Fig. 3. Venn diagrams of the number of hoverfly species trapped in Harv, UnHarv50 and UnHarv100 in 2004 and 2007. The number in the bottom-right hand corner indicates the number of species caught during the other year in the set of the three stands sampled, which were not caught during that year.

\section{Hoverfly sampling and definition of functional groups and guilds}

Since a Malaise trap is the most appropriate device for quantitative studies of hoverflies when few sites are sampled (Sommaggio, 1999) hoverflies were sampled using two Malaise traps per stand. Sampling was carried out at two-weekly intervals from May to October in two non-consecutive years, 2004 and 2007, in order to obtain data for two independent years. All the samples were identified to the species by one of the authors (JPS) who also conserved the insects.

Using the Syrph the Net database (Speight et al., 2013), we defined guilds with respect to (1) forest dependency (strictly, optionally, or strictly not forest species for reproduction), (2) migratory behaviour (strongly, weakly or non migrant) and (3) commensalism (yes or no). In addition functional groups in terms of (4) the feeding behaviour of the larvae (living plants, living animals, saproxylic) and (5) adult feeding behaviour (pollen and nectar gathered from flowers or leaves, Homopteran honeydew) (see details in Table S2). Syrph the Net provides the quality of the relationship between a life history trait and a species based on a

2004

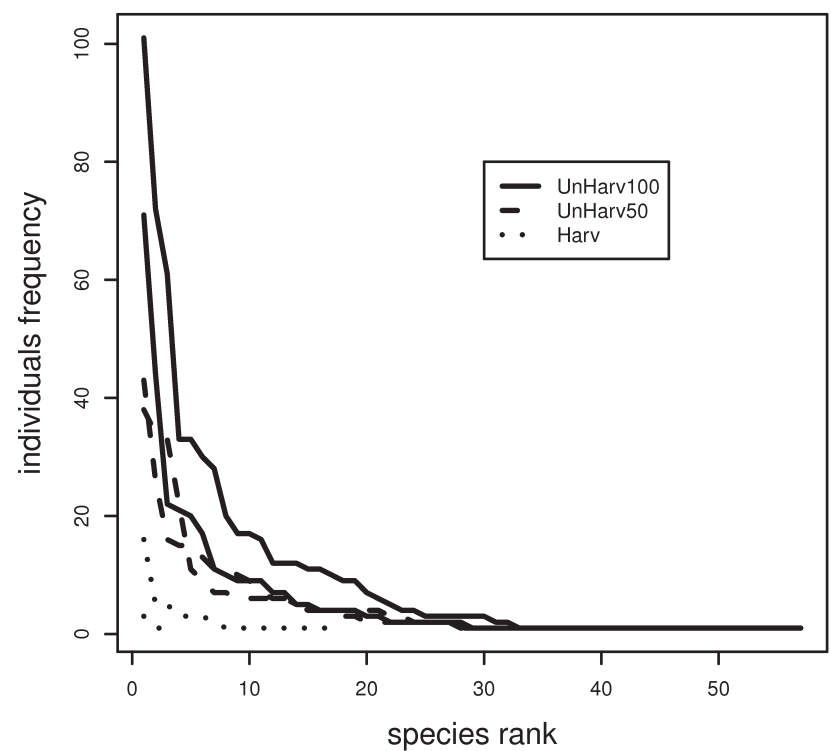

fuzzy coding system, from blank, which means no association, to 3 for a maximum association. In this study, we only used code 3 . In order to characterize the variations in hoverfly assemblages between stands, species richness, abundance and diversity of the whole community, guilds and functional groups were determined for each stand.

\section{Calculations and statistical procedures}

In order to highlight differences and similarities in composition of the different samples caught by the six Malaise traps during the two years, a hierarchical clustering analysis (hclust function) was carried out on the abundance data, using a Bray-Curtis distance matrix and the vegdist function (vegan package, Oksanen et al., 2013).

Functional diversity (FD) was estimated using Petchey \& Gaston's (2006) method, and a dendrogram produced based on the life history trait distance matrix (Jaccard distance, vegan package; Oksanen et al., 2013), for all the species caught. The total length of the dendrogram branches was calculated in the same way as for "phylogenetic diversity" (picante package, Kembel et al., 2014) for the dendrogram that included all the species recorded in this study (forest FD) and the assemblages of species recorded in each stand. Results were standardized by expressing them as a percentage of the forest FD. The ratios of FD to species richness (RS) were calculated to express the functional redundancy of species belonging to the same group: the higher the ratio, the smaller the functional redundancy.

All analyses were performed using statistical software R 3.0.2 (R Development Core Team, 2014).

\section{RESULTS}

\section{Species richness and abundance}

A total of 2,374 hoverflies was collected from the Malaise interception traps in the three stands in the two years (Table 3). They were identified as belonging to 46 genera and 104 species. Since we chose the three stands within a gradient of structural heterogeneity (attributed mainly to occurrence and intensity of harvesting) and since we tried to control environmental parameters such as altitude, for-

2007

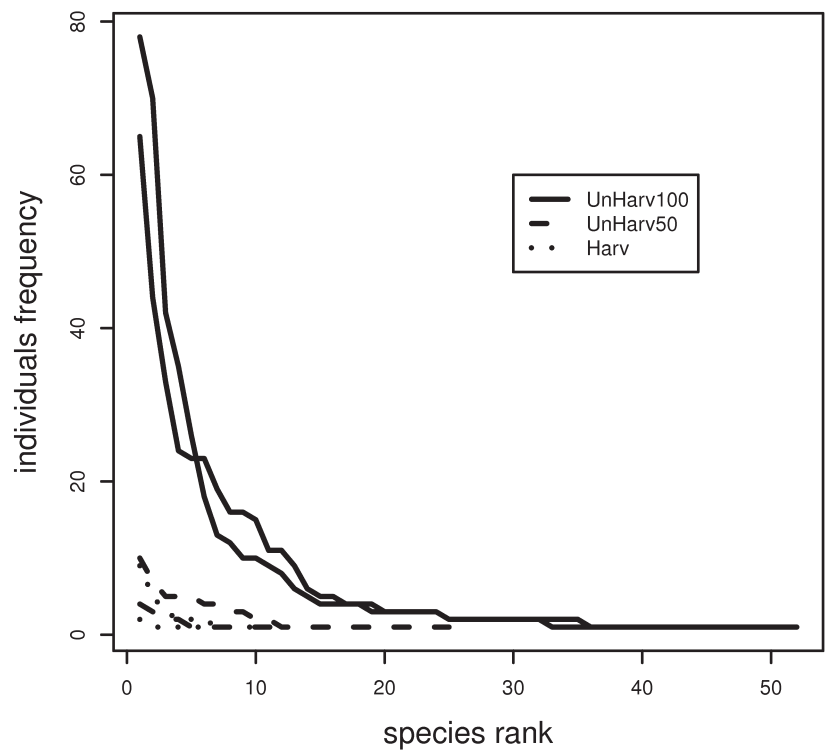

Fig. 4. Abundance of hoverfly species (ranked in decreasing order) in the three beech-fir stands studied (Harv, UnHarv50 and UnHarv100) in 2004 and 2007. 
TABLE 3. Hoverfly assemblages in the three stands studied, in 2004 and 2007 and per trap (A and B). Numbers indicate the abundance of each species.

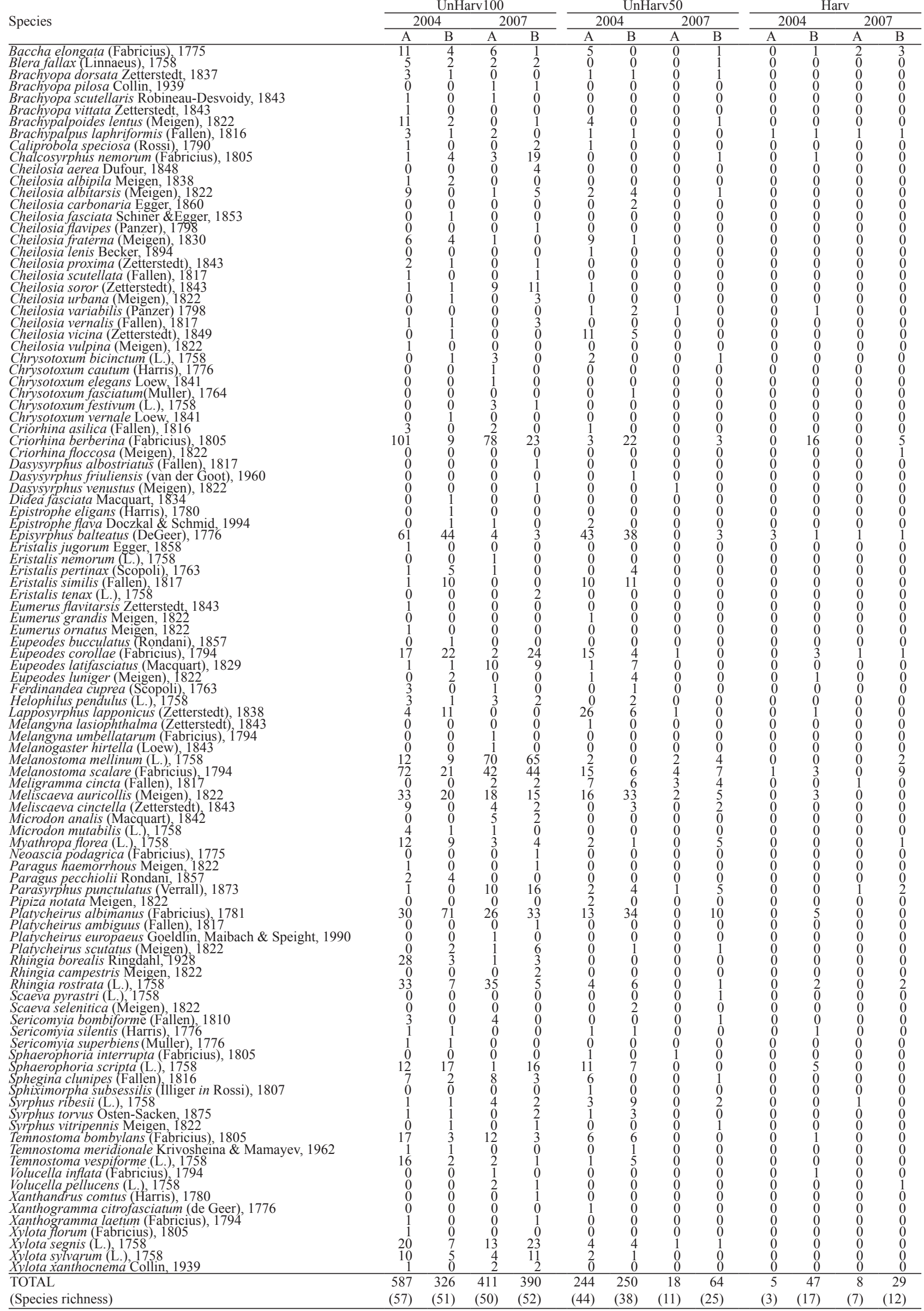




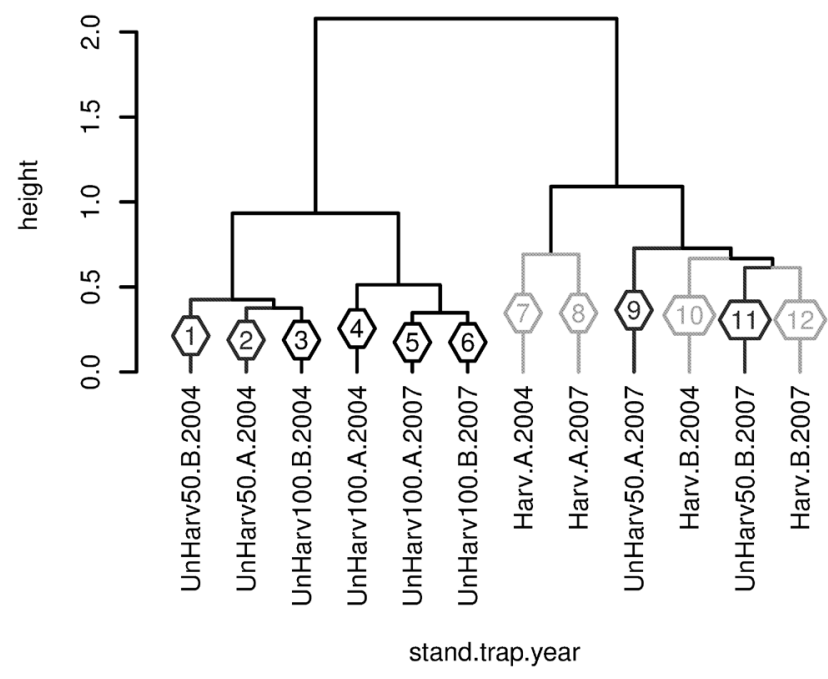

Fig. 5. Cluster dendrogram based on a hierarchical clustering analysis of hoverfly samples trapped per stand, year and trap. The first node of the cluster dendrogram completely separated Harv and Unharv100. In contrast, the samples for Unharv50 were split according to the year sampled: 2004 close to UnHarv100 and 2007 close to Harv.

est type, etc., we expected nested assemblages. However 12 species: Cheilosia carbonaria Egger, 1860, C. lenis Becker, 1894, Chrysotoxum fasciatum (Muller), 1764, Dasysyrphus friuliensis (van der Goot), 1960, Eumerus grandis Meigen, 1822, Melangyna lasiophthalma (Zetterstedt), 1843, Pipiza notata Meigen, 1822 (syn. Pipiza bimaculata Meigen, 1822), Scaeva pyrastri (L.) 1758, S. selenitica (Meigen) 1822, Sphaerophoria interrupta (Fabricius), 1805, Sphiximorpha subsessilis (Illiger in Rossi), 1805, Xanthogramma citrofasciatum (de Geer), 1876, and a subset of five of these species, were only trapped in UnHarv50, in 2004 and 2007, respectively (Fig. 3). One species, Criorhina floccosa (Meigen) 1822, was only trapped in Harv in both 2004 and 2007. Twenty-one species were trapped in 2007 but not in 2004, while 29 species were trapped in 2004 and not in 2007 (Fig. 3). Species strictly associated with fir, e.g. Blera fallax (L.), 1758 and Rhingia borealis (Ringdahl, 1928) were not recorded in Harv (Table 3 ).

Per stand, the highest numbers of both species and individuals were recorded in UnHarv100 and lowest in Harv, both in 2004 and 2007 (Fig. 4 and Table 3).

The first node of the cluster dendrogram completely separated Harv and Unharv100. In contrast, the samples collected in Unharv50 were split according to the year collected: 2004 close to UnHarv100 and 2007 close to Harv (Fig. 5). This result indicated a clear response of hoverfly assemblages to the gradient in stand heterogeneity, by partitioning the distributions of hoverfly abundances according to the three levels of heterogeneity, based on variation among years and traps.

\section{Distribution of guilds and functional groups in the three stands, and functional diversity}

The species richness within the guilds and functional groups was always ranked in the following order: Un-
TABLE 4. Specific richness (SR) and functional diversity (FD) of hoverflies recorded for the three stands studied, expressed as percentages of the total FD of the forest.

\begin{tabular}{lcc}
\hline Stands & SR (\%) & FD (\%) \\
\hline UnHarv100 & 86.54 & 95.96 \\
UnHarv50 & 57.69 & 75.30 \\
Harv & 23.08 & 45.18 \\
\hline
\end{tabular}

Harv100 > UnHarv50 > Harv (Table S4 and Fig. 6). Strictly forest species were only caught in UnHarv100. There was a notable difference in the abundance recorded at the three sites, with the same rank as above (Fig. 6, S2 and S3).

FD was positively correlated with species richness (RS). Both FD and SR decreased dramatically from UnHarv100 to Harv but not in the same proportion. The FD:RS ratio increased from UnHarv100 (1.11) to UnHarv50 (1.31) and then Harv (1.96) (Table 4).

\section{DISCUSSION}

\section{Hoverfly assemblages}

Interestingly, even though the species richness and abundance of hoverflies decreased from the most heterogeneous (UnHarv100) to the least heterogeneous stand (Harv), we did not simply record an impoverishment in the syrphid fauna in parallel with decrease in structural heterogeneity. Quite a large number of species were only recorded in the stand of intermediate-heterogeneity (UnHarv50). These were mainly phytophagous species (such as Cheilosia spp. and Eumerus grandis) or aphidophagous species that feed on aphids infesting low growing or small plants (such as Melangyna lasiophthalma, Scaeva spp., Pipiza spp., Sphaerophoria interrupta), tall plants (such as Dasysyrphus friuliensis) or even the roots of plants (such as Chrysotoxum fasciatum, Xanthogramma citrofasciatum). Although the microhabitats of these larvae were also present in the most heterogeneous stand, it is possible that the stand of intermediate-heterogeneity provided microhabitats of higher quality or a better match for the requirements of the larvae. Only two microphagous species were trapped only in the intermediate and least heterogeneous stand: Sphiximorpha subsessilis and Criorhina floccosa, respectively, but, in both cases, only one specimen was trapped in the entire study. The larval microhabitat of Sphiximorpha subsessilis is sap-flows on old Abies alba trees (Speight et al., 2013), always rare, even in forests that have not been logged for a very long time (Larrieu et al., 2014). The larvae of Criorhina floccosa are mainly found in the wet decaying roots of Fagus stumps (Speight et al., 2013).

Hoverflies differed both in species richness and abundance in 2004 and 2007. We checked that no silvicultural intervention or wide-scale event (such as windthrow) had occurred in the stands sampled during the period between these two years, but cannot be sure that nothing changed since we did not record the stand descriptors in 2007, which would have enabled us to measure possible slight changes. However, changes in deadwood and tree-microhabitat patterns are long-term processes (e.g. Larrieu et al., 2012). 

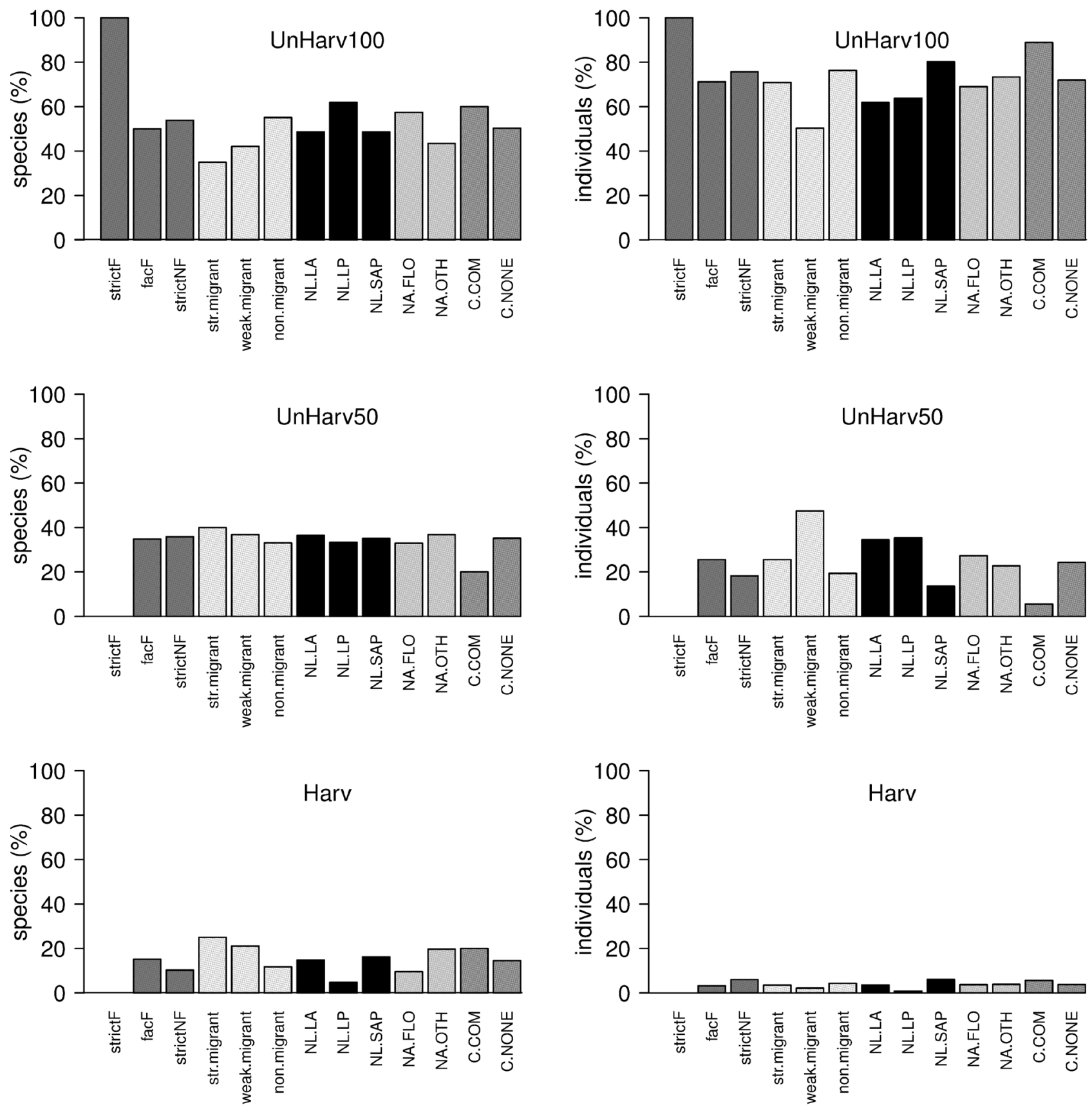

Fig. 6. Distribution in the different stands of the number of hoverfly species (left) and individuals (right), expressed as a proportion of the total number per guild or functional group. strctF: strictly forest species, facF: optionally forest species, strctNF: strictly non forest species; str.migrant: strongly migrant species, weak.migrant: weakly migrant species, non.migrant: non migrant species; NL.LA: zoophagous larvae, NL.LP: phytophagous larvae, NL.SAP: saproxylic larvae; NA.FLO: adults feed on pollen and nectar gathered from flowers, NA.OTH: adults feed on pollen gathered on upper surface of leaves or adults feed on sap-runs; C.COM: commensal species; C.NONE: non commensal species. See Table S2 for a description of the guilds and functional groups; from left to right, shades of grey distinguish successively the five following categories: forest dependency, migrants, feeding behaviour of larvae, feeding behaviour of adults and commensalism.

\section{Guild sensitivity and functional diversity}

We recorded a dramatic decrease in species richness and individual abundance in the guilds and functional groups in intermediate-heterogeneous stands and the least heterogeneous, except for the guild of strongly migrant species. We assume this is linked to the reduction in stand heterogeneity. According to Huston (1994), the last stage of this process is the reduction in the number of functional groups.
However, members of all the guilds and functional groups were present in the three stands, except the strictly forest species, which were only recorded in the most heterogeneous stand. Nevertheless, from point of view of the insurance hypothesis (Yachi \& Loreau, 1999), this decrease in species richness and individual abundance might impair the potential resilience of the intermediate-heterogeneous stand, and above all in the least heterogeneous stand, when 
disturbed. Furthermore, the disappearances of species and decrease in a stand's structural heterogeneity could have a cascade effect since these disappearances could in themselves also reduce the structural heterogeneity of the stand (Therriault \& Kolasa, 2000). Ultimately, functional loss cannot be correctly evaluated by using only a coarse functional diversity measure based on available life history traits and should be supplemented by determining the species richness and abundance within each functional group.

The most heterogeneous stand had the biggest proportion of very large trees, and Reemer (2005) demonstrates that an increase in the average age and size of trees plus the conservation of old and dead trees results in the spatial dispersion of hoverfly saproxylic species. Under-storey tree and shrub species were also more varied in the most heterogeneous than in the intermediate-heterogeneous stand and above all in the least heterogeneous stand. This diversity could explain the higher species richness of aphidophagous and foliage or root-linked hoverflies we recorded in the most heterogeneous stand (Speight et al., 2013). Only the most heterogeneous stand had a species-rich herb layer. The presence of this layer could account on the one hand for the richest and most abundant phytophagous and zoophagous hoverfly communities, and, on the other hand, for the richest and most abundant flower-visiting communities (Speight et al., 2013). Similarly, Fayt et al. (2006) record that a well developed and species-rich herbaceous plant layer in an open stand with large trees is the main factor associated with the presence of saproxylic hoverflies in beech and oak forests.

Functional diversity (FD) proved to be very representative of the general trend recorded for species richness and abundance in the stands sampled, but FD decreased more slowly than species richness. Although species richness and FD are positively correlated (Petchey \& Gaston, 2006) the least heterogeneous stand had an intermediate FD since most guilds and functional groups were recorded there. The method we used to calculate FD does not account for species abundance, which might partly ensure the effectiveness of ecological services provided by the functional group.

\section{Perspectives for further research}

This pilot study used a relatively small sample to explore whether the structural heterogeneity of a stand influences species richness or abundance of hoverflies at the stand scale, focusing on both montane beech fir forest, which to our knowledge has not been done in previous studies on hoverflies, and variables that have rarely been used in previous studies, such as an accurate description of both deadwood items and tree-microhabitats. Unfortunately, the lack of replication prevented us from fully analyzing the links between factors that determine heterogeneity and hoverfly assemblages, thus preventing the generalization of our results. However, since our results revealed big differences, further biodiversity studies should be conducted in a larger sample of stands, which should include replicate stands to cover as far as possible the gradient of structural heterogeneity, as well as in other forest types, e.g. in lowland and/ or fragmented forests. We would recommend conducting such surveys using emergence traps in addition to Malaise traps. Since abundance was the most sensitive variable associated with structural changes recorded in this study, we recommend that this variable be recorded in future hoverfly surveys. Furthermore, as flowers appear to be a key feature, a more precise survey of the diversity of the shrub and herbaceous plant layers should be conducted during the period when hoverflies are sampled. Finally, even though our sample did not allow us to highlight the role of deadwood and tree-microhabitats as drivers of hoverfly diversity at the stand level, we also recommend accurately recording them in future studies, since the larval stages of many hoverfly species depend on them (Speight et al., 2013).

\section{CONCLUSION}

Although most of the functional groups were recorded in the three stands, species richness, abundance and functional diversity decreased dramatically from the most heterogeneous to the least heterogeneous stand. However, the species assemblages in the less heterogeneous stands were not perfect subsets of that in the most heterogeneous stand, as some additional species not found in the most heterogeneous stand were also present. Further research is needed to clarify which structural factors drive this decrease.

ACKNOWLEDGEMENTS. This study was financed with the help of European funds (FEDER) as well as French grants (Conseil regional de Midi-Pyrénées, Conseil général des Hautes-Pyrénées). We thank the owners of the forests, especially J.-L. Chaire, for their welcome, A. Delarue and B. Carrère for their help in the field, and P. Holder, D. Goodfellow and M. Hewison for checking the English. We wish also to thank C. Bouget, M. Deconchat, J. Beck and the two anonymous reviewers who provided constructive comments that helped us improve the manuscript.

\section{REFERENCES}

Bardat J., Bioret F., Botineau M., Boullet V., Delpech R., Géhu J.M., Haury J., Lacoste A., Rameau J.C., Royer J.M., Roux G. \& Touffet J. 2004: Prodrome des Végétations de France. MNHN, Paris, $171 \mathrm{pp}$.

BitterLich W. 1984: The Relascope Idea: Relative Measurements in Forestry. Commonwealth Agricultural Bureaux, Slough, 242 pp.

Blondel J. \& Cuvillier R. 1977: Une méthode simple et rapide pour décrire les habitats d'oiseaux: le stratiscope. - Oikos 29: 326-331.

Christensen M., Hahn K., Mountford E., Odor P., Standovar T., Rozenbergar D., Diaci J., Wijdeven S., Meyer P., Winter S. \& VRSKa T. 2005: Dead wood in European beech (Fagus sylvatica) forest reserves. - Forest Ecol. Manag. 210: 267-282.

Dupouey J.L., Bachacou J., Cosserat R., Aberdam S., Vallauri D., Chappart G. \& Corvisier de Villèle M.A. 2007: Vers la réalisation d'une carte géoréférencée des forêts anciennes de France. - Le Monde des Cartes 191: 85-98.

EUFORGEN 2012: Distribution Map of Silver Fir (Abies alba) and European Beech (Fagus sylvatica). http://www.euforgen. org.

Fayt P., Dufrene M., Branquart E., Hastir P., Pontegnie C., Henin J.M. \& Versteirt V. 2006: Contrasting responses of saproxylic insects to focal habitat resources: the example of long- 
horn beetles and hoverflies in Belgian deciduous forests. $-J$. Insect Conserv. 10: 129-150.

Frank J. \& VolKmar W. 2006: Episyrphus balteatus: an example of pollination efficiency in hoverflies. In: 91st Annual Meeting of the Ecological Society of America (ESA), Memphis, Tennessee, August 2006.

Gibson R.H., Nelson I.L., Hopkins G.W., Hamlett B.J. \& Memмотт J. 2006: Pollinator webs, plant communities and the conservation of rare plants: arable weeds as a case study. $-J$. Appl. Ecol. 43: 246-257.

Gittings T., O’Halloran J., Kelly T. \& Giller P.S. 2006: The contribution of open spaces to the maintenance of hoverflies (Diptera, Syrphidae) biodiversity in Irish plantation forests. Forest Ecol. Manag. 237: 290-300.

Good J. \& Speight M.C.D. 1996: Convention relative à la conservation de la vie sauvage et du milieu naturel de l'Europe: Les invertébrés saproxyliques et leur protection à travers l'Europe. Council of Europe, Strasbourg, 58 pp.

Greenberg C.H., McLeod D.E. \& Loftis D.L. 1997: An Oldgrowth Definition for Western and Mixed Mesophytic Forest. USDA Forest Service, Asheville, 14 pp.

Groot M. \& Bevk D. 2012: Ecosystem services and phenology of hoverflies (Diptera: Syrphidae) in a Slovenian forest stand. - Les (Ljubljana) 64: 123-128.

Humphrey J.W., Hawes C., Peace A.J., Ferris-Kaan R. \& Jukes M.R. 1999: Relationships between insect diversity and habitat characteristics in plantation forests. - Forest Ecol. Manag. 113: $11-21$.

Huston M.A. 1994: Biological Diversity. The Coexistence of Species on Changing Landscapes. Cambridge University Press, Cambridge, $681 \mathrm{pp}$.

Jarlan A., DE Oliveira D. \& Gingras J. 1997: Effects of Eristalis tenax (Diptera: Syrphidae) pollination on characteristics of greenhouse sweet pepper fruits. - J. Econ. Entomol. 90: $1650-1654$.

KeIL P. \& Konvicka M. 2005: Local species richness of Central European hoverflies (Diptera: Syrphidae): a lesson taught by local faunal lists. - Divers. Distrib. 11: 417-426.

Kembel S.W., Ackerly D.D., Blomberg S.P., Will K., Cornwell W.K., Peter D., Cowan P.D., Helmus M.R., Morlon H. \& WebB C.O. 2014: Package 'picante'. $R$ Tools for Integrating Phylogenies and Ecology Ver. 1.6-2. 56 pp. Available from http://cran.r project.org/web/packages/picante/picante.pdf

Larrieu L., Cabanettes A. \& Delarue A. 2012: Impact of sylviculture on dead wood and on the distribution and frequency of tree microhabitats in montane beech-fir forests of the Pyrenee. - Eur. J. Forest Res. 131: 773-786.

Larrieu L., Cabanettes A., Brin A., Bouget C. \& Deconchat M. 2014: Tree microhabitats at the stand scale in montane beechfir forests: practical information for taxa conservation in forestry. - Eur. J. Forest Res. 133: 355-367.

Loreau M., Naeem S., Inschausti P., Bengtsson J., Grime J.P., Hector A., Hooper D.U., Huston M.A., Raffaelli D., Schmid B., Tilman D. \& Wardle D.A. 2001: Biodiversity and ecosystem functioning: Current knowledge and future challenges. Science 294: 804-808.

MCPFE 2007: State of Europe's Forests. The MCPFE Report on Sustainable Forest Management in Europe. Ministerial conference on the protection of forests in Europe, Warsaw, 263 pp.

MÉTAILIÉ J.P. 2001: Un patrimoine historico-environnemental: Les forêts pastorales dans les Pyrénées. In: Paysages, territoires et aménagement dans le sud de la France. Actes du 126ème congrés national des sociétés historiques et scientifiques, Toulouse. CTHS, Paris, pp. 33-47.
Müller J., Brunet J., Brin A., Bouget C., Brustel H., Bussler H., Förster B., Isacsson G., Köhler F., Lachat T. \& Gossner M. 2012: Implications from large-scale spatial diversity patterns of saproxylic beetles for the conservation of European beech forests. - Insect Conserv. Div. 6: 162-169.

Nelson E.H., Hogg B.N., Mills N.J. \& Daane K.M. 2012: Syrphid flies suppress lettuce aphids. — BioControl 57: 819-826.

Nilsson S.G., Niklasson M., Hedin J., Aronsson G., Gutowski J.M., Linder P., Ljungberg H., Mikusinnski G. \& Ranius T. 2002: Densities of large living and dead trees in old-growth temperate and boreal forests. - Forest Ecol. Manag. 161: 189-204.

Oksanen J., Blanchet F.G., Kindt R., Legendre P., Minchin P.R., O'Hara R.B., Simpson G.L., Solymos P.M., Stevens H.H. \& WAGNer H. 2013: Package 'vegan'. http://cran.r-project.org/ web/packages/vegan/vegan.pdf.

Petchey O.L. \& Gaston K.J. 2006: Functional diversity: back to basics and looking forward. - Ecol. Lett. 9: 741-758.

R Core Team 2014: R: A Language and Environment for Statistical Computing. R Foundation for Statistical Computing, Vienna. URL http://www.R-project.org/.

REEMER M. 2005: Saproxylic hoverflies benefit by modern forest management (Diptera: Syrphidae). - J. Insect Conserv. 9: 49-59.

Ricarte A., Marcos-Garcia M. \& Moreno C.E. 2011: Assessing the effects of vegetation type on hoverfly (Diptera: Syrphidae) diversity in a Mediterranean landscape: implications for conservation. - J. Insect Conserv. 15: 865-877.

Rotheray G.E. \& GILBERT F. 2011: The Natural History of Hoverflies. Forrest Text, Ceredigion, $348 \mathrm{pp}$.

Smith H., Chaney W. \& Bensen T. 2008: Role of syrphid larvae and other predators in suppressing aphid infestations in organic lettuce on California's Central Coast. - J. Econ. Entomol. 101: $1526-1532$.

SommagGio D. 1999: Syrphidae: can they be used as environmental bioindicators? - Agric. Ecosyst. Environ. 74: 343-356.

Sommaggio D. \& Burgio G. 2003: Role of Diptera Syrphidae as landscape indicators: analysis of some case studies in Northern Italy. - Bull. OILB/SROP 26: 145-150.

SPEIGHT M.C.D. 1989: Saproxylic Invertrebrates and their Conservation. Nature and Environment No. 42. Council of Europe, Strasbourg, $79 \mathrm{pp}$.

Speight M.C.D., Castella E. \& Sarthou J.P. 2013: StN 2013. In Speight M.C.D., Castella E., Sarthou J.-P. \& Vanappelghem C. (eds): Syrph the Net on CD, Issue 9. The database of European Syrphidae. Syrph the Net Publications, Dublin.

Therriault T.W. \& Kolasa J. 2000: Explicit links among physical stress, habitat heterogeneity and biodiversity. - Oikos 89: 387-391.

Tscharntke T., Clough Y., Wanger T.C. Jackson L., Motzke I., Perfecto I., Vandermeer J. \& Whitbread A. 2012: Global food security, biodiversity conservation and the future of agricultural intensification. - Biol. Conserv. 151: 53-59.

WinTER S. \& MÖLLER G.C. 2008: Microhabitats in lowland beech forests as monitoring tool for nature conservation. - Forest Ecol. Manag. 255: 1251-1261.

YACHI S. \& LOREAU M. 1999: Biodiversity and ecosystem productivity in a fluctuating environment: The insurance hypothesis. — Proc. Natn. Acad. Sci. U.S.A. 96: 1463-1468.

Received October 5, 2014; revised and accepted June 26, 2015 Prepublished online July 21, 2015 
TABLE S1. Scale of decay stages used to characterize dead wood items.

\begin{tabular}{cl}
\hline Decay stages & \multicolumn{1}{c}{ Definitions } \\
\hline I & $\begin{array}{l}\text { Fresh deadwood (<1 year), hard and not rotten. Phloem alive or at least perceptible. More than 95\% of the bark is still } \\
\text { attached to the stem. }\end{array}$ \\
\hline II & $\begin{array}{l}\text { 2-3 year old deadwood, still hard. Phloem dead and not perceptible. The knife blade enters maximum 1 or } 2 \mathrm{~cm} \text {, only } \\
\text { parallel to the wood fiber. }\end{array}$ \\
\hline III $\quad \begin{array}{l}\text { Deadwood starts to get rotten. The outer wood is soft, the inner wood still not rotten. The bark is partially fallen down. } \\
\text { The knife blade enters } 3 \text { to } 5 \mathrm{~cm} \text {, at least parallel to the wood fiber. No material loss (current volume = initial volume). }\end{array}$ \\
IV $\quad \begin{array}{l}\text { Deadwood is clearly rotten. The knife blade enters up to hilt. Bark is mainly missing or bark is only soft and unconsoli- } \\
\text { dated at stem. Material loss (current volume < initial). }\end{array}$ \\
V $\quad \begin{array}{l}\text { Wood almost disintegrated, very spongy or powdery, almost incohesive. Large loss of material. Presence in wood of } \\
\text { species belonging to soil-dwelling fauna. }\end{array}$
\end{tabular}

TABLE S2. Groups of guilds $(G)$ and types of functional groupings (FG) of hoverflies with their ecological significance in relation to structural heterogeneity of stands.

Guilds (G) and functional groupings (FG)

of hoverflies

Ecological significance in relation to forest ecosystem characteristics

G (1) - Strictly forest species

for the reproduction (strctF)

G (1') - Optionally forest species $\quad$ For laying eggs, these species need to find appropriate microhabitats within or outside

for the reproduction (facF) a forest

G(1") - Strictly non forest species

for the reproduction (strctNF)

G (2) - Strongly migrant species

(str.migrant)

G (2') - Weakly migrant species

(weak.migrant)

G (2") - Non migrant species

(non.migrant)

For laying eggs, these species need to find appropriate microhabitats outside a forest

G (3) - Commensal species (C.COM) $\quad \begin{aligned} & \text { Species whose larvae are commens, } \\ & \text { ptera (bumble bees, wasps, ants) }\end{aligned}$

Species repeatedly recorded as undergoing migrational activity, they can look for trophic resources (both for adult and larval stages) far from their larval development place Species occasionally recorded as exhibiting migrational activity, they usually look for trophic resources (both for adult and larval stages) not so far from their larval development place

Self explanatory, they usually look for trophic resources (both for adult and larval stages) not so far from their larval development place

G(3') - Non commensal species

(C.NONE)

FG (4') - Zoophagous larvae (feeding

on living animals) (NL.LA)

FG (4) - Phytophagous larvae (feeding

in living plants) (NL.LP)

Self explanatory

FG (4") - Saproxylic larvae (feeding on Species dependent upon dead or dying wood or upon the activities of other saproxylic decaying wood-related material) (NL.SAP) insects. They participate in the organic matter and nutrient recycling.

FG (5) - Adults feeding on pollen and Self explanatory. These species need flowers within or in the close vicinity of their habinectar gathered on flowers (NA.FLO)

Species whose larvae are predatory of soft-bodied insects (mainly aphids and also caterpillars, mealybugs, psyllids)

Species whose larvae feed on the tissues of living, non-woody plants

FG (5') - Adults feeding on (wind-trans-

ported) pollen gathered on upper surface of

leaves, or feeding on sap-runs (NA.OTH) tat, and they participate in the pollination of the plants visited.

Self explanatory. These species do not need flowers within or in the close vicinity of their habitat, and they do not participate in the pollination of the plants visited.

TABLE S3. Main characteristics of stand structural heterogeneity; mean frequencies and standard errors into brackets.

\begin{tabular}{|c|c|c|c|}
\hline \multirow{2}{*}{ Variables } & \multicolumn{3}{|c|}{ Stands } \\
\hline & UnHarv100 & UnHarv50 & Harv \\
\hline Base empty cavities ha ${ }^{-1}$ & $6.01(1.06)$ & $33.61(6.91)$ & $33.07(13.0)$ \\
\hline Trunk empty cavities ha- ${ }^{-1}$ & $3.55(2.14)$ & $4.06(2.16)$ & $1.66(1.66)$ \\
\hline Base cavities with mould ha ${ }^{-1}$ & $15.58(4.91)$ & $3.13(1.43)$ & $9.47(3.14)$ \\
\hline Trunk cavities with mould ha ${ }^{-1}$ & $13.45(4.26)$ & $12.14(4.21)$ & $8.39(1.82)$ \\
\hline Dendrothelms ha- ${ }^{-1}$ & $7.7(3.75)$ & $21.52(12.7)$ & $60.84(8.31)$ \\
\hline Cracks ha $^{-1}$ & $3.96(2.17)$ & $4.32(2.48)$ & $2.34(1.19)$ \\
\hline Saproxylic fungi ha ${ }^{-1}$ & $1.47(0.81)$ & $8.86(2.19)$ & $0.35(0.35)$ \\
\hline Missing bark $\mathrm{ha}^{-1}$ & $9.69(4.90)$ & $76.2(14.2)$ & $82.68(6.53)$ \\
\hline $\operatorname{Logs}\left(\mathrm{m}^{3} \mathrm{ha}^{-1}\right)$ & $20.6(6.53)$ & $37.5(9.33)$ & $3.79(2.17)$ \\
\hline Snags $\left(\mathrm{m}^{3} \mathrm{ha}^{-1}\right)$ & $16.5(3.29)$ & $16.7(6.23)$ & $0.21(0.21)$ \\
\hline High stumps $\left(\mathrm{m}^{3} \mathrm{ha}^{-1}\right)$ & $2.97(0.70)$ & $3.32(0.57)$ & $4.72(0.60)$ \\
\hline Deadwood decay stage $1\left(\mathrm{~m}^{3} \mathrm{ha}^{-1}\right)$ & $4.2(2.35)$ & $3.33(2.61)$ & $0(0)$ \\
\hline Deadwood decay stage $2\left(\mathrm{~m}^{3} \mathrm{ha}^{-1}\right)$ & $3.8(1.56)$ & $19.7(8.40)$ & $0(0)$ \\
\hline Deadwood decay stage $3\left(\mathrm{~m}^{3} \mathrm{ha}^{-1}\right)$ & $9.92(4.77)$ & $15.0(4.03)$ & $6.15(1.91)$ \\
\hline Deadwood decay stage $4\left(\mathrm{~m}^{3} \mathrm{ha}^{-1}\right)$ & $13.41(4.13)$ & $14.8(3.38)$ & $2.57(0.64)$ \\
\hline Deadwood decay stage $5\left(\mathrm{~m}^{3} \mathrm{ha}^{-1}\right)$ & $0.63(0.44)$ & $2.5(1.85)$ & $0(0)$ \\
\hline Deadwood diversity (number of categories) & $6(0.82)$ & $9.2(1.05)$ & $5(0.65)$ \\
\hline
\end{tabular}


TABLE S4. Sample details per functional groups (FG) and guilds (G).

\begin{tabular}{|c|c|c|c|c|}
\hline Category & UnHarv100 & UnHarv50 & Harv & Total \\
\hline FG "Spp. with saproxylic larvae": species - Both years & 18 & 13 & 6 & 20 \\
\hline FG "Spp. with saproxylic larvae": species - 2004 & 16 & 11 & 5 & 18 \\
\hline FG "Spp. with saproxylic larvae": species - 2007 & 14 & 5 & 3 & 16 \\
\hline FG "Spp. with saproxylic larvae": individuals - Both years & 382 & 65 & 29 & 476 \\
\hline FG "Spp. with saproxylic larvae": individuals - 2004 & 207 & 58 & 21 & 286 \\
\hline FG "Spp. with saproxylic larvae": individuals - 2007 & 175 & 7 & 8 & 190 \\
\hline FG "Spp. with phytophagous larvae": species - Both years & 13 & 7 & 1 & 16 \\
\hline FG "Spp. with phytophagous larvae": species - 2004 & 11 & 7 & 1 & 14 \\
\hline FG "Spp. with phytophagous larvae": species - 2007 & 9 & 2 & 0 & 10 \\
\hline FG "Spp. with phytophagous larvae": individuals - Both years & 74 & 41 & 1 & 116 \\
\hline FG "Spp. with phytophagous larvae": individuals - 2004 & 34 & 39 & 1 & 74 \\
\hline FG "Spp. with phytophagous larvae": individuals -2007 & 40 & 2 & 0 & 42 \\
\hline FG "Spp. with zoophagous larvae": species - Both years & 36 & 27 & 11 & 44 \\
\hline FG "Spp. with zoophagous larvae": species - 2004 & 25 & 24 & 8 & 33 \\
\hline FG "Spp. with zoophagous larvae": species - 2007 & 29 & 16 & 6 & 32 \\
\hline FG "Spp. with zoophagous larvae": individuals - Both years & 643 & 359 & 37 & 1039 \\
\hline FG "Spp. with zoophagous larvae": individuals - 2004 & 397 & 313 & 23 & 733 \\
\hline FG “Spp. with zoophagous larvae": individuals - 2007 & 246 & 46 & 14 & 306 \\
\hline FG "Spp. whose adults feed on flowers": species - Both years & 54 & 31 & 9 & 62 \\
\hline FG "Spp. whose adults feed on flowers": species -2004 & 42 & 28 & 8 & 51 \\
\hline FG "Spp. whose adults feed on flowers": species - 2007 & 38 & 15 & 5 & 40 \\
\hline FG "Spp. whose adults feed on flowers": individuals - Both years & 523 & 207 & 28 & 758 \\
\hline FG "Spp. whose adults feed on flowers": individuals - 2004 & 292 & 181 & 14 & 487 \\
\hline FG "Spp. whose adults feed on flowers": individuals - 2007 & 231 & 26 & 14 & 271 \\
\hline FG "Spp. whose adults feed on others": species - Both years & 33 & 28 & 15 & 38 \\
\hline FG "Spp. whose adults feed on others": species -2004 & 25 & 25 & 9 & 29 \\
\hline FG "Spp. whose adults feed on others": species - 2007 & 29 & 15 & 9 & 33 \\
\hline FG "Spp. whose adults feed on others": individuals - Both years & 1175 & 365 & 61 & 1601 \\
\hline FG "Spp. whose adults feed on others": individuals -2004 & 613 & 309 & 38 & 960 \\
\hline FG "Spp. whose adults feed on others": individuals - 2007 & 562 & 56 & 23 & 641 \\
\hline G "Strictly forest spp. for reproduction": species - Both years & 3 & 0 & 0 & 3 \\
\hline G "Strictly forest spp. for reproduction": species - 2004 & 1 & 0 & 0 & 1 \\
\hline G "Strictly forest spp. for reproduction": species - 2007 & 3 & 0 & 0 & 3 \\
\hline G "Strictly forest spp. for reproduction": individuals - Both years & 8 & 0 & 0 & 8 \\
\hline G "Strictly forest spp. for reproduction": individuals - 2004 & 1 & 0 & 0 & 1 \\
\hline G "Strictly forest spp. for reproduction": individuals - 2007 & 7 & 0 & 0 & 7 \\
\hline G "Facultatively forest spp. for reproduction": species - Both years & 66 & 46 & 20 & 78 \\
\hline G "Facultatively forest spp. for reproduction": species - 2004 & 50 & 42 & 14 & 63 \\
\hline G "Facultatively forest spp. for reproduction": species - 2007 & 51 & 24 & 11 & 54 \\
\hline G "Facultatively forest spp. for reproduction": individuals - Both years & 1364 & 491 & 62 & 1917 \\
\hline G "Facultatively forest spp. for reproduction": individuals - 2004 & 725 & 417 & 33 & 1175 \\
\hline G "Facultatively forest spp. for reproduction": individuals - 2007 & 639 & 74 & 29 & 742 \\
\hline G "Strictly non forest spp. for reproduction": species - Both years & 21 & 14 & 4 & 23 \\
\hline G "Strictly non forest spp. for reproduction": species - 2004 & 18 & 12 & 3 & 19 \\
\hline G "Strictly non forest spp. for reproduction": species - 2007 & 15 & 6 & 3 & 18 \\
\hline G "Strictly non forest spp. for reproduction": individuals - Both years & 340 & 82 & 27 & 449 \\
\hline G "Strictly non forest spp. for reproduction": individuals - 2004 & 185 & 74 & 19 & 278 \\
\hline G "Strictly non forest spp. for reproduction": individuals - 2007 & 155 & 8 & 8 & 171 \\
\hline G "Strongly migrant spp.": species - Both years & 7 & 8 & 5 & 9 \\
\hline G "Strongly migrant spp.": species -2004 & 6 & 6 & 4 & 7 \\
\hline G "Strongly migrant spp.": species - 2007 & 6 & 5 & 3 & 7 \\
\hline G "Strongly migrant spp.": individuals - Both years & 385 & 139 & 19 & 543 \\
\hline G "Strongly migrant spp.": individuals - 2004 & 197 & 127 & 13 & 337 \\
\hline G "Strongly migrant spp.": individuals - 2007 & 188 & 12 & 6 & 206 \\
\hline G "Weakly migrant spp.": species - Both years & 8 & 7 & 4 & 8 \\
\hline G "Weakly migrant spp.": species - 2004 & 7 & 7 & 2 & 8 \\
\hline G "Weakly migrant spp.": species - 2007 & 6 & 5 & 2 & 7 \\
\hline G "Weakly migrant spp.": individuals - Both years & 142 & 134 & 6 & 282 \\
\hline G "Weakly migrant spp.": individuals - 2004 & 87 & 115 & 4 & 206 \\
\hline G "Weakly migrant spp.": individuals - 2007 & 55 & 19 & 2 & 76 \\
\hline G "Non migrant spp.": species - Both years & 70 & 42 & 15 & 81 \\
\hline G "Non migrant spp.": species - 2004 & 54 & 38 & 11 & 65 \\
\hline G "Non migrant spp.": species - 2007 & 52 & 20 & 9 & 56 \\
\hline G "Non migrant spp.": individuals - Both years & 1131 & 288 & 64 & 1483 \\
\hline G "Non migrant spp.": individuals - 2004 & 610 & 237 & 35 & 882 \\
\hline G "Non migrant spp.": individuals - 2007 & 521 & 51 & 29 & 601 \\
\hline G "Commensal spp.": species - Both years & 3 & 1 & 1 & 4 \\
\hline G "Commensal spp.": species - 2004 & 1 & 1 & 0 & 2 \\
\hline G “Commensal spp.”: species - 2007 & 3 & 0 & 1 & 3 \\
\hline G "Commensal spp.": individuals - Both years & 16 & 1 & 1 & 18 \\
\hline G "Commensal spp.": individuals - 2004 & 5 & 1 & 0 & 6 \\
\hline G "Commensal spp.": individuals - 2007 & 11 & 0 & 1 & 12 \\
\hline G "Non commensal spp.": species - Both years & 80 & 56 & 23 & 92 \\
\hline G "Non commensal spp.": species - 2004 & 64 & 50 & 17 & 76 \\
\hline G "Non commensal spp.”: species - 2007 & 60 & 29 & 13 & 66 \\
\hline G "Non commensal spp.": individuals - Both years & 1679 & 567 & 88 & 2234 \\
\hline G "Non commensal spp.": individuals - 2004 & 900 & 486 & 52 & 1438 \\
\hline G "Non commensal spp.": individuals - 2007 & 779 & 81 & 36 & 896 \\
\hline
\end{tabular}



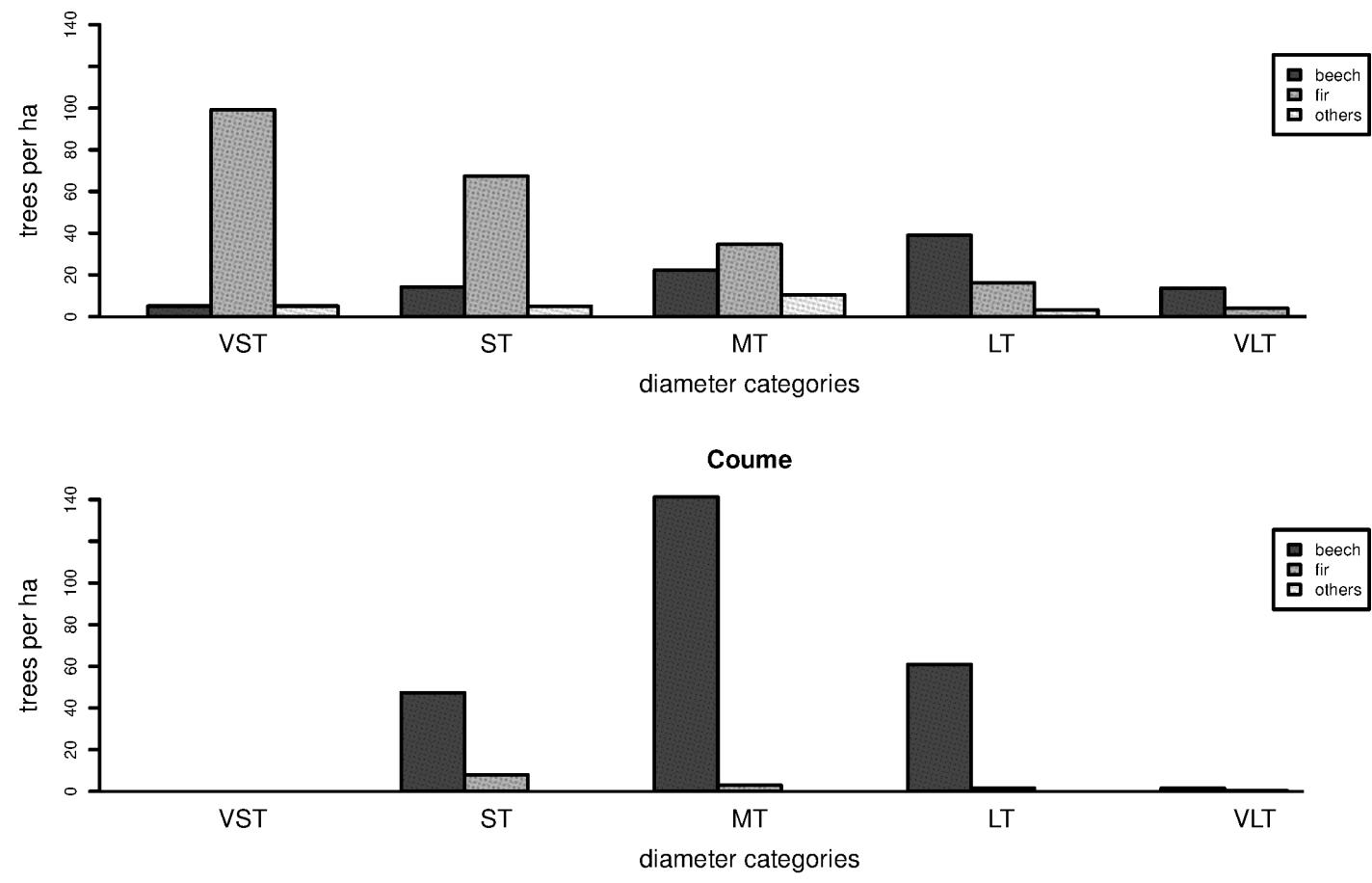

Seti

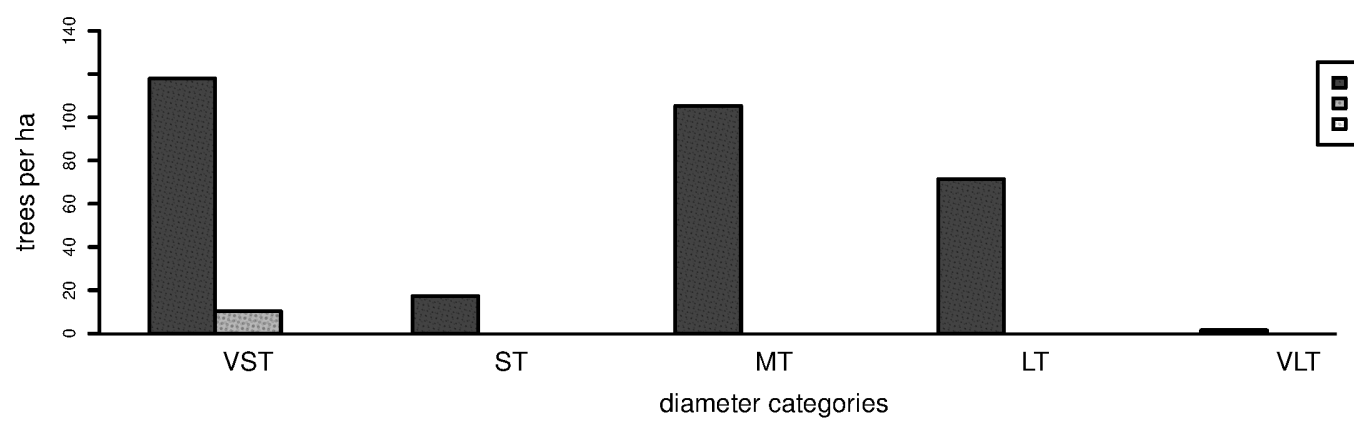

Fig. S1. Dendrometrical structure of the three stands studied. UnHarv100 (= "Plagnet"): unlogged since 1900; UnHarv50 (= "Coume"): logged in 1950 and unlogged since; Harv (= "Seti"): logged regularly during the last 25 years. Dbh categories: $17.5 \mathrm{~cm}<$ small tree $(\mathrm{ST})<27.5 \mathrm{~cm}$; medium tree $(\mathrm{MT})<47.5 \mathrm{~cm}$; large tree $(\mathrm{LT})<67.5 \mathrm{~cm}$; very large tree (VLT) $\geq 67.5 \mathrm{~cm}$ for broadleaved species, and $17.5 \mathrm{~cm}<\mathrm{ST}<27.5 \mathrm{~cm}$; MT $<42.5 \mathrm{~cm} ; \mathrm{LT}<62.5 \mathrm{~cm}$; VLT $\geq 62.5 \mathrm{~cm}$ for conifers. 

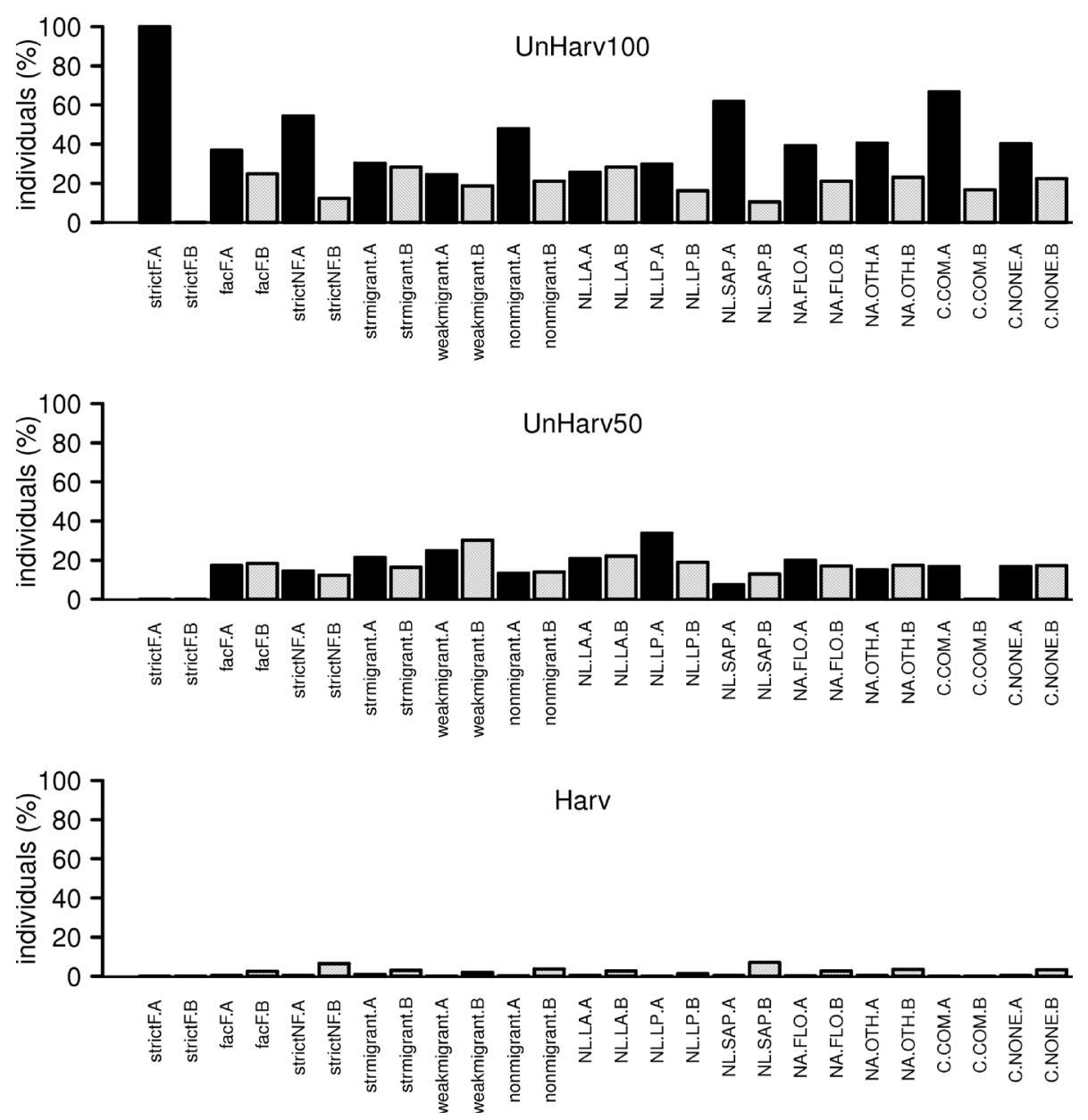

Fig. S2. Distribution per stand of the number of hoverfly individuals caught in 2004, expressed by the proportion of total amount per guild or functional group. strctF: strictly forest species for the reproduction, facF: optionally forest species for the reproduction, strctNF: strictly non forest species for the reproduction; str.migrant: strongly migrant species, weak.migrant: weakly migrant species, non.migrant: non migrant species; NL.LA: zoophagous larvae, NL.LP: phytophagous larvae, NL.SAP: saproxylic larvae; NA.FLO: adults feeding on pollen and nectar gathered on flowers, NA.OTH: adults feeding on pollen gathered on upper surface of leaves or feeding on sap-runs; C.COM: commensal species, C.NONE: non commensal species. See Table S2 for guild and functional group description. A and B indicate the sample split par Malaise. 

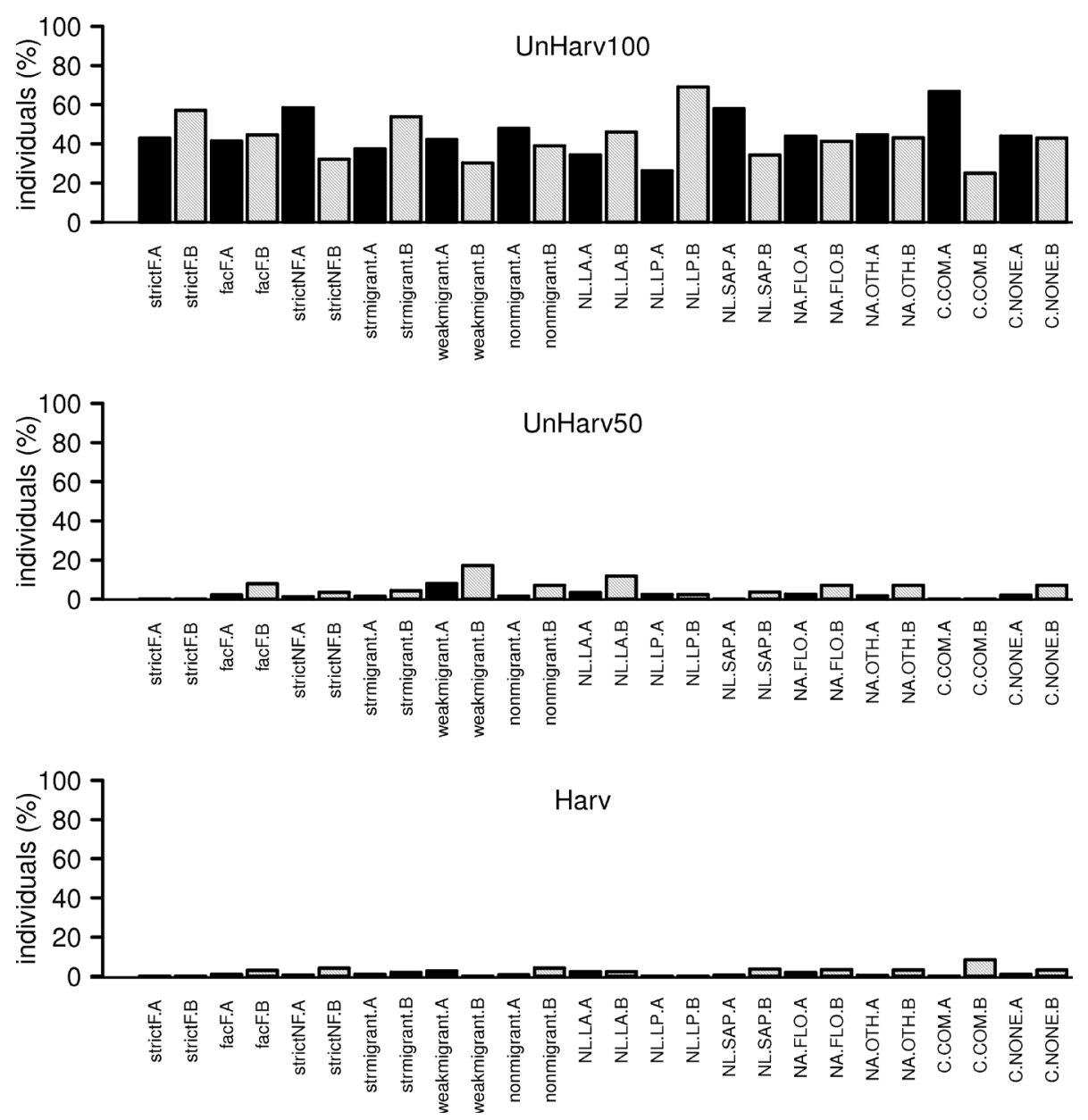

Fig. S3. Distribution per stand of the number of hoverfly individuals caught in 2007, expressed by the proportion of total amount per guild or functional group. strctF: strictly forest species for the reproduction, facF: optionally forest species for the reproduction, strctNF: strictly non forest species for the reproduction; str.migrant: strongly migrant species, weak.migrant: weakly migrant species, non.migrant: non migrant species; NL.LA: zoophagous larvae, NL.LP: phytophagous larvae, NL.SAP: saproxylic larvae; NA.FLO: adults feeding on pollen and nectar gathered on flowers, NA.OTH: adults feeding on pollen gathered on upper surface of leaves or feeding on sap-runs; C.COM: commensal species, C.NONE: non commensal species. See Table S2 for guild and functional group description. A and B indicate the sample split par Malaise. 